\title{
Cracow functional corridors as a possibility for the revitalization of the urban rail-related areas
}

\section{Krakowskie korytarze funkcjonalne możliwością rewitalizacji miejskich obszarów kolejowych}

\begin{abstract}
The industrial technological advance and progressive urban expansion throughout the centuries left the railways with their infrastructure and facilities as degraded and devastated areas in the well urbanized centers of many contemporary Polish cities. In Cracow, the rail lines became a difficult to cross spatial barrier and previously used warehouses lost their historical function and became abandoned. The presented study demonstrates the metropolitan rail's significant influence on the city's urban spatial structure. The aim is to discuss the problems and opportunities of rail-related areas revitalization as the proposal of urban design solutions are presented.
\end{abstract}

Keywords: spatial planning, metropolitan rail, urban revitalization

\section{Streszczenie}

Rozwój technologiczny przemysłu oraz postępująca ekspansja miast na przestrzeni wieków pozostawiły kolejnictwo wraz z jego infrastrukturą i obiektami towarzyszącymi jako zdegradowane i zdewastowane obszary w intensywnie zurbanizowanych centrach wielu współczesnych polskich miast. W Krakowie linie kolejowe stały się uciążliwą do pokonania barierą przestrzenną, a użytkowane wcześniej obiekty magazynowe utraciły swoją historyczną funkcję i zostały opuszczone. Przedstawione badania wykazują istotny wpływ kolei metropolitalnej na strukturę przestrzenną miasta. W celu omówienia problemów oraz szans i możliwości rewitalizacji obszarów kolejowych zaprezentowany zostanie projekt zagospodarowania przestrzennego miasta.

Słowa kluczowe: planowanie przestrzenne, kolej metropolitalna, rewitalizacja miasta 


\section{INTRODUCTION}

The invention of the steam engine had a vast influence over different fields of the economy as well as on the image of early 19th century cities. Brand-new transportation system in the form of railways and train stations was an impulse for rapid urban development. In most cases, previously vacant suburban and rural areas were used to provide proper infrastructure together with diversified rail-related function. Train stations were intentionally built in the outstanding forms of distinguished architecture and presentable character. Prestigious boulevards connecting them to the city centres took shape. Along the rail line, industrial and warehousing clusters with necessary multifamily housing were formed. The railways stimulated urban expansion. That process stretched the cities' urban structures towards the rail-dedicated areas. By that time rail lines, although dominant in the landscape, were not a barrier for integrity nor for spatial arrangement of the cities.

Throughout the centuries, the share of rail within the transportation industry weakened significantly. Modern industry got independent of the rail services and, as a result, plenty of industrial buildings were left abandoned. Furthermore, the mass transportation systems matured, leaving behind complicated rail infrastructure or excessive functional buildings, which gave way to compact automatic and electronic systems. The process of degradation of areas along the rail lines and train stations began.

\section{CRACOW'S HISTORICAL RAIL SYSTEM ${ }^{1}$}

In order to tighten economic influences within the Austro-Hungarian Empire, a rail route master plan leading from Vienna to Galicia, was approved for construction in 1834 . With access to strategic resources of Silesian coal on the way, the Emperor Ferdinand's Privileged Northern Railway was meant to reach valuable salt mines in Bochnia and Wieliczka. In the vicinity of the Free City of Cracow, it was supposed to run south of the city and along the right bank of the Vistula river through Podgórze. A vital change to its path placed Lviv at the end of its course through an extension of over $300 \mathrm{~km}$, but Cracow was still excluded from the upcoming rail line. Within the next ten years, plans for two other major railways in the region were introduced. Lines heading from Warsaw and Wrocław were about to meet with the Northern line by the western Galician border. In 1844, to establish train connection, a Cracow-Upper Silesia Railway was proposed, providing a linkage between the city and the upcoming railroads already being built. Construction of the train station in the north-east and a line leading west started immediately. In 1846, the city lost its independence and got annexed by Austria. The next year the first steam engine train appeared at the station in Cracow. Most significant was a direct connection to Vienna which started to operate in 1848 after all the railways got combined together. 
For the purpose of the train station, a complex of essential buildings and infrastructure was established on the previous suburban 2 plantation lands and between Lubicz and Pawia streets. Buildings of various functions like characteristic steam locomotive depot with engine car turntable, multiple warehouses with loading ramps, a water tower with water crane and multifamily buildings provided proper service for the trains, as well as the accommodation for the railway company employees. A splendid passenger building was located in the south of the area. Designed by engineer Piotr Rosenbaum, it was arranged out of three functional sections of buildings with the train shed in the middle. The western passenger building with Neo-Renaissance style facade was composed of three 2-storey segments with entrances. The middle segment was noticeably taller and wider. They were structurally and functionally connected together by a setback of ground level hallways (III. 1). Spacious interiors accommodated waiting halls, ticket offices, a restaurant and railway station offices. For the passengers' convenience the two train platforms were covered with an iron-constructed, arched and entirely glazed roof spanning over three tracks and supported by ornamented cast iron pillars. The trains were entering the station through three architecturally unique arched gates rhythmically composed with arched windows of both northern and southern facades. A dedicated driveway led from the poplar tree lined Lubicz St. to an expansive horse carriage square by the main entrance. The building sat enclosed by the train station gardens.

From 1856, an advantageous connection from Cracow to Vienna via Trzebinia and Oświęcim finally became available. This connection omitted the Prussian rail network, saving travel duration time and distance. Also the extended east rail line to Dębica through Płaszów and Bochnia was completed. The demand for train services rapidly increased. Over time, the primary passenger building was expanded twice, doubling its ground floor square meterage. Around that time, constructors of the Eastern Railway were faced with previously nonexistent engineering problems. To avoid collision between the railway and the city road system, a street underpass was dug on Lubicz St. The rail bridge supported by structural retaining walls on each side of the street, was designed by architect Teodor Talowski and built in 1898. The walls were finished with decorative stone blocks; ornamented stairs provided access from the lowered street level, right to the train station square. This allowed for an uninterrupted traffic flow of the street under the prioritized railway and provided unobstructed pedestrian access. In the vicinity of the train station along Lubicz St. functional urban clusters evolved with Neo-Renaissance tenement apartment buildings for railway deputies and customs officers, as well as industrial ones with, for example, a brewery complex. Lubicz St. became an architecturally distinguished urban avenue.

Another challenge on the way was to cross the Vistula river. In place of wooden bridges, a remarkable stone and brick arched viaduct over the Old Vistula and an inventive, over $200 \mathrm{~m}$ long, steel truss bridge over the Vistula were successively opened in 1863 and 1864 . Those bridges were prepared for future expansion of the rail line with additional tracks. Furthermore, to solve train traffic inconveniences, an alternative rail line encircling the city from the west 
was built in 1888. An approximately $8 \mathrm{~km}$ long line connected industrial areas of Bonarka and Wieliczka's salt warehouses of Płaszów, located mostly south of the city and along the right bank of the Vistula. This rail line operated for over two decades and connected Bonarka, Podgórze and Płaszów train stations to the network. With numerous freight side tracks, railways influenced the local industry and strengthened the economy. A track within the modernized riverbanks of Vistula and plans for a near-future river harbour facilitated and increased inland waterways shipping of coal and salt. In 1913, the dedicated cargo train station with an excess of branch lines and complicated system of sidetracks with loading ramps and storehouses started to operate in the north of the city (in the Krowodrza district along the 'old' Western Railway).

First horse-driven tram line built in 1881 stretched out north to south of the city, forming a communicational spine linking the essential historical parts of the city together. Starting from aside of the train station square, the line routed across the Cracow's main market square (Rynek Główny), alongside of Wawel Royal Castle and further through Kazimierz and until the Podgórski bridge over the Vistula. With the technological advances of electricity ${ }^{3}$, until 1912, seven electrified tram lines were available, all crossed together on the Rynek and coming from each side and every corner of it. Tramways operating throughout the structure of city's public spaces helped to integrate the city within its borders and became a primary city public transportation system.

The Galician rail network was constantly being improved, providing more connections with other cities in the region. In 1861 tracks reached Lviv. However, although most of the railways were single-track until the 1890s, in 1895 the express trains were able to reach Cracow from Vienna in approx. 6 hours and Lviv in 10 hours. Further expansions of the Galician railways connected the Empires of Austria, Germany, Prussia, Russia, Hungary and Romania. With the possibility to transfer goods from east to west and north to south, a European railway network evolved. At the intersection of those geographical axes, where the first pan-European transportation corridors started to form, there stood Cracow.

\section{CRACOW FORTRESS}

The remarkable geopolitical position of Cracow was historically emphasized by Tadeusz Kościuszko, who improved the defensive system of the city in the late $18^{\text {th }}$ century. Fortifications, which began to be built in the second half of the 19th century, formed a system that was structurally and technologically revolutionary for the modern era. Fundamentally, the Cracow Fortress was a complex military system based on two functional rings of fortifications, designed as a strategic stronghold, able to confront militaristic movements from the north and east and particularly of Russian Empire towards Vienna.

The inner circle consisted primarily of a chain of bastions and defensive embankment walls built over the years 1855-1870. This was supplemented with the (discussed) western bypass 
rail line, part of which ran atop the embankments, along with train station on Zwierzyniec and a dedicated steel truss road-rail bridge over the Vistula. With critical bastions and forts, this linear system rather tightly enclosed the urban structure of the city. Additionally, a protected safety zone forbade any construction in front of the defensive walls. Whereas the outer circle consisted of individual forts, in fact it was connected with a sophisticated road system built especially for the military purpose with a total length of over $100 \mathrm{~km}$. The most impressive Kościuszko Citadel was built southeast of the city. It was constructed around an artificial mound built until 1823 as a monument in the memory of T. Kościuszko. The construction of the Cracow Fortress significantly transformed the image of the city (III. 2). As a technologically advanced and far-reaching in purpose system it became socially admired. In spite of a military compound, it became a tourist attraction. A monumental in landscape Kościuszko Citadel inspired an artist and painter, Stanisław Wyspiański, for a series of impressionistic landscapes titled The Kościuszko Mound view from the window of the artist's studio and completed in $1905^{4}$. These unique pictures of Kościuszko Citadel in a background and the inner embankments with train tracks seen upclose present the Cracow Fortress in its glory and splendour.

In 1906, the western embankments were dismantled and the area was flattened, which gave an opportunity for the city expansion. Six years later, preceded by the urban design and planning competition from 1910, the Greater Cracow Masterplan was settled. It proposed a refinement of the post-fortified areas into a chain of tree lined avenues with a median of orderly arranged urban greenery, forming a green belt of prominent boulevards with a combination of continuous public space along. Analogous transformation had happened before in Cracow, when the medieval city walls were taken apart in the early 19th century. Historical fortifications turned into the city's basic greenery system ${ }^{5}$. Multiple Vistula river regulation works conducted at the turn of the century resulted in covering up the riverbeds of the royal millrace of the Rudawa river and the Old Vistula. Boulevards built over the partially vaulted millrace canal and ground leveled river improved the road system and enriched the urban greenery. Buildings risen along the Retoryka St. and Dietla St. formed irregular urban clusters, naturally following the curvy line of the old riverbeds. A city park network formed together with the promenade along the refurbished Vistula riverbanks. These intertwined urban structures were noticed in the year 1912 by the famous Ebenezer Howard who commented on the city's richness of greenery and its ring-plan system, describing Cracow as a naturally evolved garden city ${ }^{6}$.

\section{SCIENTIFIC GUIDELINES}

Each of the discussed historical processes permanently transformed the image and the urban structure of the city. Although the evolution of fortification and river systems integrated the city structure, the rail system gradually became an inconvenient 
transportation and spatial barrier in form of a dominant urban landscape edge splitting the constantly expanding city. However, the fortification transformation is a perfect example of a barrier breaking process accomplished to provide a practically organized public space. Consequently, the historical transformation processes shaped the urban spatial structure available and functioning in the contemporary city.

The modern revitalization process can use elements of unbuilt areas associated with historical fortification system, together with functionally deserted transportation areas. Properly conducted, it intensifies the breaking process of a rail line barrier. As a result of advantageous strategy implementation and necessary interventions, breaking the existing physical and spatial barrier of the rail lines is possible to accomplish. Therefore, effective and practical forms of architectural transformation preserve the valuable historical remnants of the fortifications and the rail heritage, generating beneficial impact over social experience and economic value of the city.

\section{URBAN DIFFICULTIES IDENTIFICATION}

The historical transformations processes awareness compiles a fundamental research background. Historical analysis operates as a necessary stage of scientific research method required for the following case study ${ }^{7}$. The presented study confronts the problematic aspects of the mid-urban context rail lines. The study objective is to overcome the urban spatial, functional and landscaping barrier of the rail lines. A site survey was conducted in the north of the Cracow's central train station over the urban areas along the historical and modern rail lines. Characteristic areas influenced by the rail system and further where noticeable landscape and functional connections happen were investigated. Exceptional attention focuses over the areas in between the railways, where the historical rail structures remained. Urban structures providing a functional connection with the city center and distant urban clusters overreaching the Opolska St. are included in the study. With the upcoming Cracow's metropolitan rail transportation system in mind, the following resources were analysed and presented in form of diagrams: land use, functional arrangement, heritage and landscape values, transportation network and environmental impact (III. 5).

Land use study indicates the absence of urban composition. Clusters of multistorey residential housing were marked as a source of significantly amplified urban traffic. General functional distribution is uneven. Commercial public services concentrate towards the historical city center. Additionally, rail lines inconveniently break the urban spatial structure and landscape into functionally and communicationally separated segments. Local recreation and public spaces occurrence is imbalanced and scattered. The lack of spatial consistency and diversified services creates unattractive urban space. Such situation creates disharmony of the city districts and divides the city into functional islands. Multifamily 
housing complexes, deprived of accompanying organized public spaces and greenery, defunct socially and economically. Post-industrial and post-rail areas are a subject of urban degradation process. Functionally deserted objects contaminate the landscape and the environment. The two renovated buildings found among the historical cargo train station complex stand as an exception. In contrast, abandoned post-fortified buildings undergo devastation. Historical fortification system fades away which rises disturbing concerns. However, multiple heritage sites and buildings are located (III. 4). Natural greenery strips along the rail lines are characterized as hard to access unavailable areas. Heritage and natural environment preservation is postulated. North to south traffic arteries cross the rail lines and serve the inhabitants of the territories even beyond the northern third bypass ring-road (Opolska St.). Major communicational strings and axes improperly collide with the rail lines and have insufficient traffic capacity. Collisions generate heavy traffic and communication inconveniences mainly throughout hierarchy issues, traffic bottlenecks (ramped tunnels, etc.) and dead-end roads, for both car and pedestrian traffic. The identified problems indicate the road system inconsistency. This affects the urban noise pollution, as well as intensifies river and air pollution generated largely by the rail and car traffic.

The Łobzów train station is the only mid-urban station present at the area of investigation. Situated in-between the specific multistorey residential housing clusters in the north and the intensively redeveloped area along the Wrocławska St. and Kijowska Ave., it appears functionally marginalized. Particularly, it is structurally embedded in the railway embankment at the edge of noticeably different urban landscapes, therefore it is perceived as a spatial and functional barrier in the area. Although dominant, the train station itself fades away within the functionally abundant yet chaotic neighborhood. Whereas visible from ground level of surrounding streets, it is neither architecturally significant nor does it have an evident connection with the road system and pedestrian access. The entrance to the platform is available by a single and unappealing staircase, accessed from half way through the dark and narrow pedestrian under passage (III. 3). Insufficient signage and lighting, along with scare and fatigued station equipment (the absence of sitting benches and electronic timetable), reflects on the functionality and a sense of security over the passengers' comfort. Finally, the Łobzów train station is not architecturally adopted for passengers with disabilities and, above all, a wheelchair user inaccessibility is unacceptable.

\section{CRACOW FUNCTIONAL CORRIDORS STRATEGY}

Functional Corridors form a consistent structure which corresponds to and transforms (if necessary) the city's urban and spatial structure. The presented concept uses Transportation Corridors and Green Corridors as tools for urban design and spatial transformations. Initially, Corridors determine critical interventions and solve local collisions in terms of urban design 
and urban spatial planning. Moreover, the CFC strategy rises the attention on problematic aspects of urban metropolitan mass transportation rail system and undertakes an attempt on breaking the rail lines' spatial barrier. As a long-term result, it demonstrates the program for the revitalization of degraded areas and integration of separated urban structures.

Cracow Functional Corridors masterplan provides a strategy for reasonable urban development and an effective urban activation. The CFC uses public spaces of presentable character, providing harmonious distribution of public and rail functions, accompanied by locally adequate commercial and service facilities. Urban functionality supplementation and diversification naturally stimulates urban structure development, resembling the historical transformation processes and reducing functional disproportions and partition of the city. Specific spatial resolutions, strengthen structural integrity and city's consistency, as the overall effect. The proposed tools provide the possibility to reinstate the post-rail areas in a continuous and progressive manner.

Corridors cross each other and combine together on many planes. At those intersections, the strategic interventions of center-forming functions occur. These stretch out from primary forms, such as a city square, a park (aerial), either rail-road and pedestrian bridge or a traffic string (linear), up to large scale urban spatial complexes (II. 8). An opportunity for economic and social development is being sought throughout the two major areas of urban spatial activation situated along the rail lines. The agricultural priority area serves the purpose of securing the urban greenery reserve zone. It is supposed to form, unobstructedly, a permaculture cultivation and non-profit, freely accessible community gardens. To a greater extent, such area impacts on adjacent residential clusters. The economic priority area is dedicated for mixed functions, preferably for the scientific research and innovative technology center. Provided with adequately scaled architecture, it creates an urban landscape transition zone, specifically for the buildings' height of the urban clusters. Additionally, the CFC program includes and encompasses vision for the revitalization of the post-industrial areas. Historical heritage preservation is a significant postulate for all of the above actions.

\subsection{TRANSPORTATION CORRIDOR}

The transportation corridor integrates rail, road, and pedestrian strings and traffic systems together. However, a railway as the functional corridor focuses on the urban metropolitan mass transportation rail system. The addition of suburban and mid-urban train stations optimizes the existing network. Through the evolution of metropolitan rail, the urban activation process becomes evident. Functional arrangement of the train stations is reexamined and balanced towards the points of intensified public interest. The train station, as a functional and spatial compound, is a significant node allowing for undisturbed (possibly shared) traffic and joining even the distant urban structures. Proposed train 
stations' prominent architecture concept is required to spark anticipated transformations as a reference to the historical impact of the Cracow's train station. Increased rail availability, functional accessibility and modern equipment provide a sense of security, and finally, initiate the urban activation.

\subsection{GREEN CORRIDOR}

A Green Corridor is a modular structure formed of linear and aerial compounds. As a branch-like network, it connects major green areas of the city (III. 7). Application of both public and private greenery preserves the structural continuity and integrity. The Green Corridor concept uses local grass surfaces, tree lines, green walls and green roofs. Natural greenery strips along the rail lines are transformed and perform as a buffering greenery, absorbing noise pollution. Along those, bicycle greenways are proposed, following the rail lines, especially towards the city center. The Green Corridor is designed to take an outstanding form of the Green Bridge concept. Appropriately, it is a pedestrian, either cycling or both functions bridge, and architecturally a structure accompanied by organized greenery resembling a continuous city park (III. 6). An idea is to screen off an excessive structure in order to provide an impression of a naturally flowing urban, still, nevertheless a green landscape. In addition, it resembles a natural process where greenery appears over unused rail lines, sidetracks and infrastructure. However, natural greenery intrusion and dense vegetation, which cause damage to the infrastructure, are undesired. Altogether, the Green Corridor is supposed to protect and preserve natural environment and valuable landscape. The essential parts of the corridor are natural river and water systems forming a natural urban waterbody. Along with the trees canopy and rich ground level foliage providing a natural habitat and migration system for avifauna and small animals of any kind, the Green Corridor is an urban, natural, living organism.

\section{CONCLUSIONS}

Throughout multiple interventions, the city becomes consistent and provides continuity of the urban structure by solving crucial problems and breaking significant barriers. The integration and urban activation of the post-industrial and post-rail areas with the modern city center is a critical process. Simultaneously, an appropriate use of public space in densely urbanized areas makes the city layout explicit. Functional diversification stimulates and controls urban evolution. The Cracow Functional Corridors strategy demonstrates the need and importance of the metropolitan rail in the city. However, it is vital to consider the historical urban evolution, which actually determined the contemporary layout of the city. Also, the modern rail system requires significant changes within the historical infrastructure 
to operate properly. The improvements to the rail network and rail infrastructure enhance the city comfort and strengthen the rail transportation significance. A balanced system of the public space and the road and transportation networks brings back the structural integrity of the city. Proper integration of the train station merges the previously split urban clusters, creating a well composed and flawlessly operating system. By means of the revitalization and the activation strategies, the constructive urban composition of the city is achieved. The presented scientific research method can effectively provide research guidelines and urban design and planning solutions for the other relevant parts of the city. Cracow Functional Corridors may stand as an example of the possibilities for the revitalization of the urban railrelated areas in other cities undergoing the urban rail transportation system modernization. 


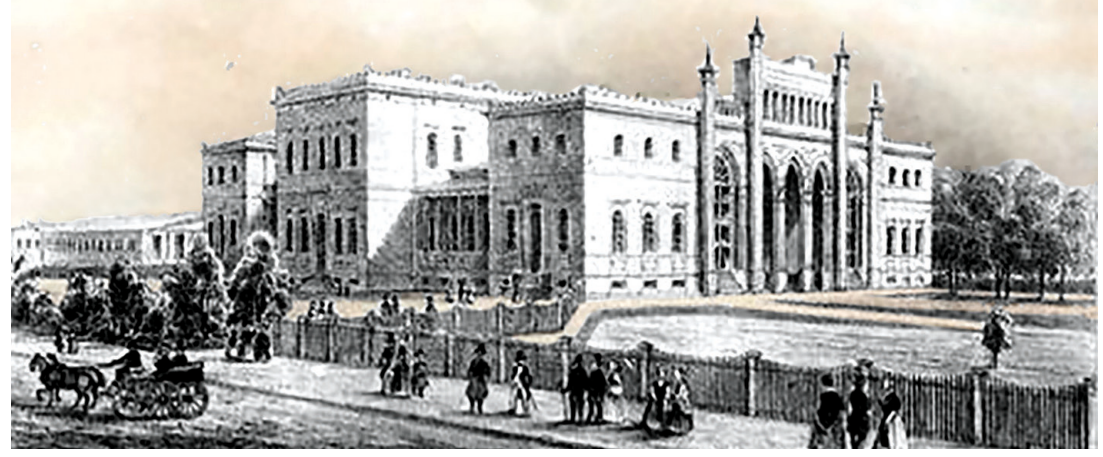

III. 1. First $19^{\text {th }}$ century Cracow historical train station II. 1. Pierwszy XIX-wieczny historyczny dworzec kolejowy w Krakowie

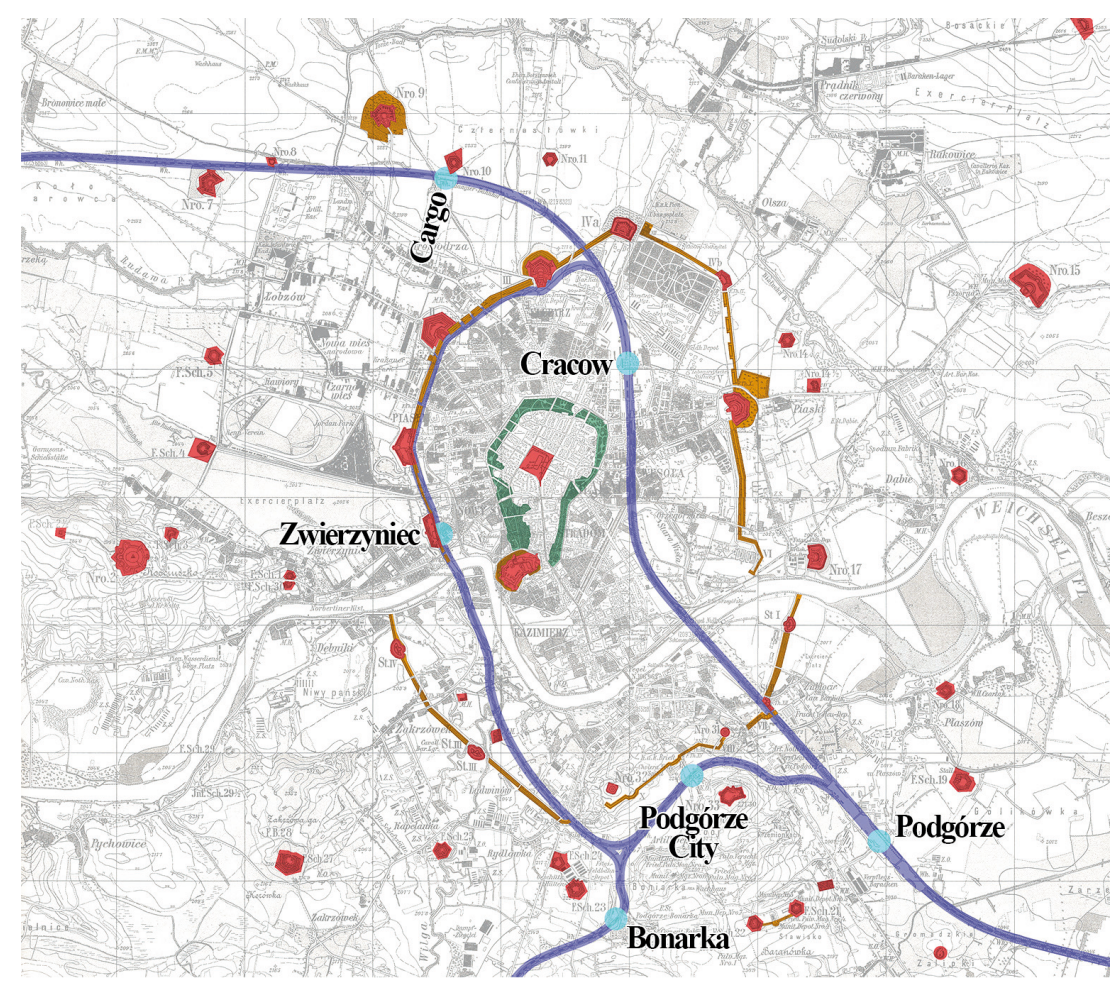

III. 2. Fortress Cracow and its railway system in early $20^{\text {th }}$ century II. 2. Twierdza Kraków i jej system kolejowy na początku XX wieku 


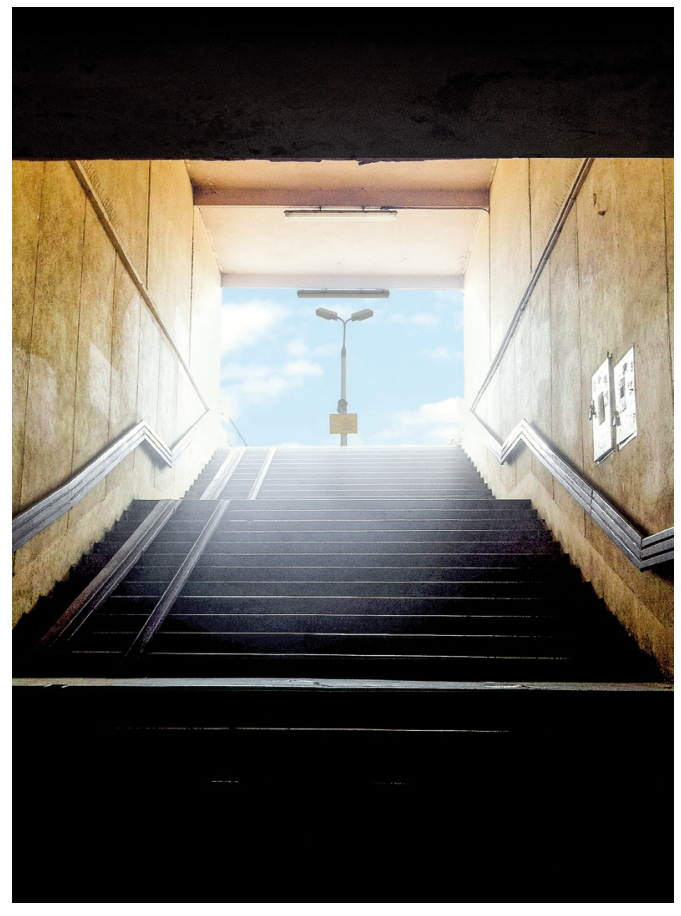

III. 3. Łobzów train st. main entrance II. 3. Stacja w Łobzowie - wejście główne

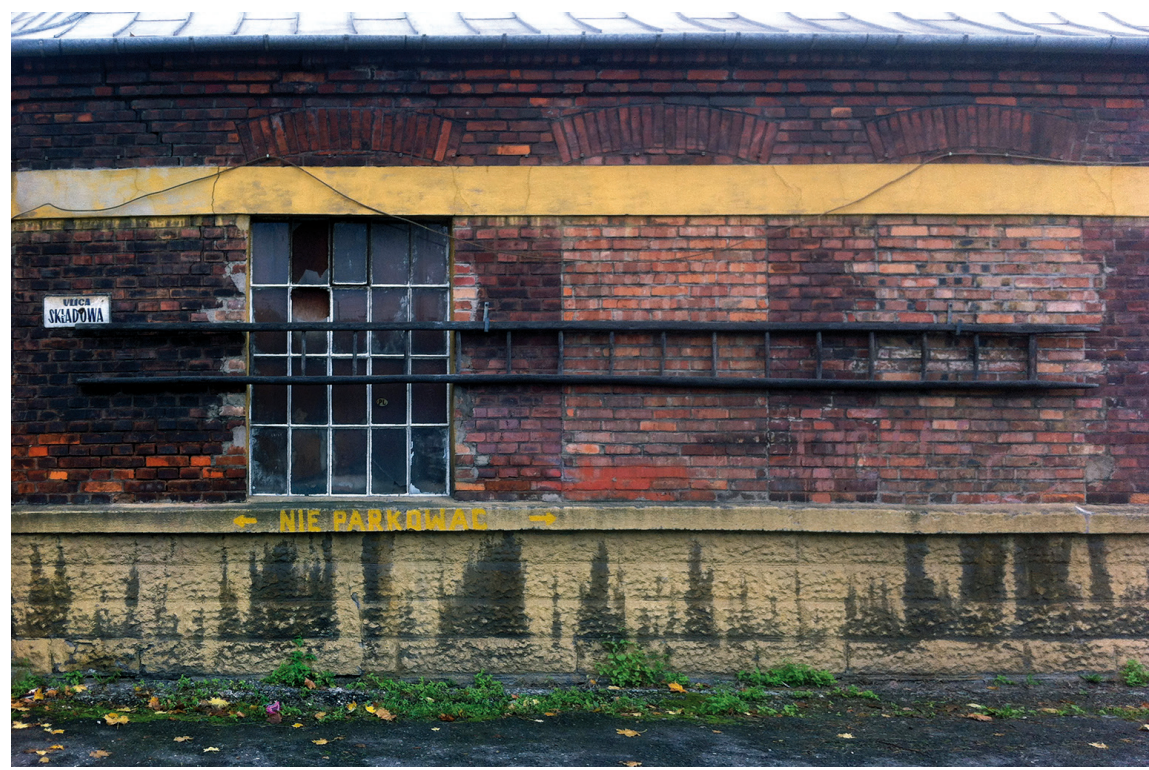

III. 4. Railway heritage site

II. 4. Zabytkowy budynek kolejowy 


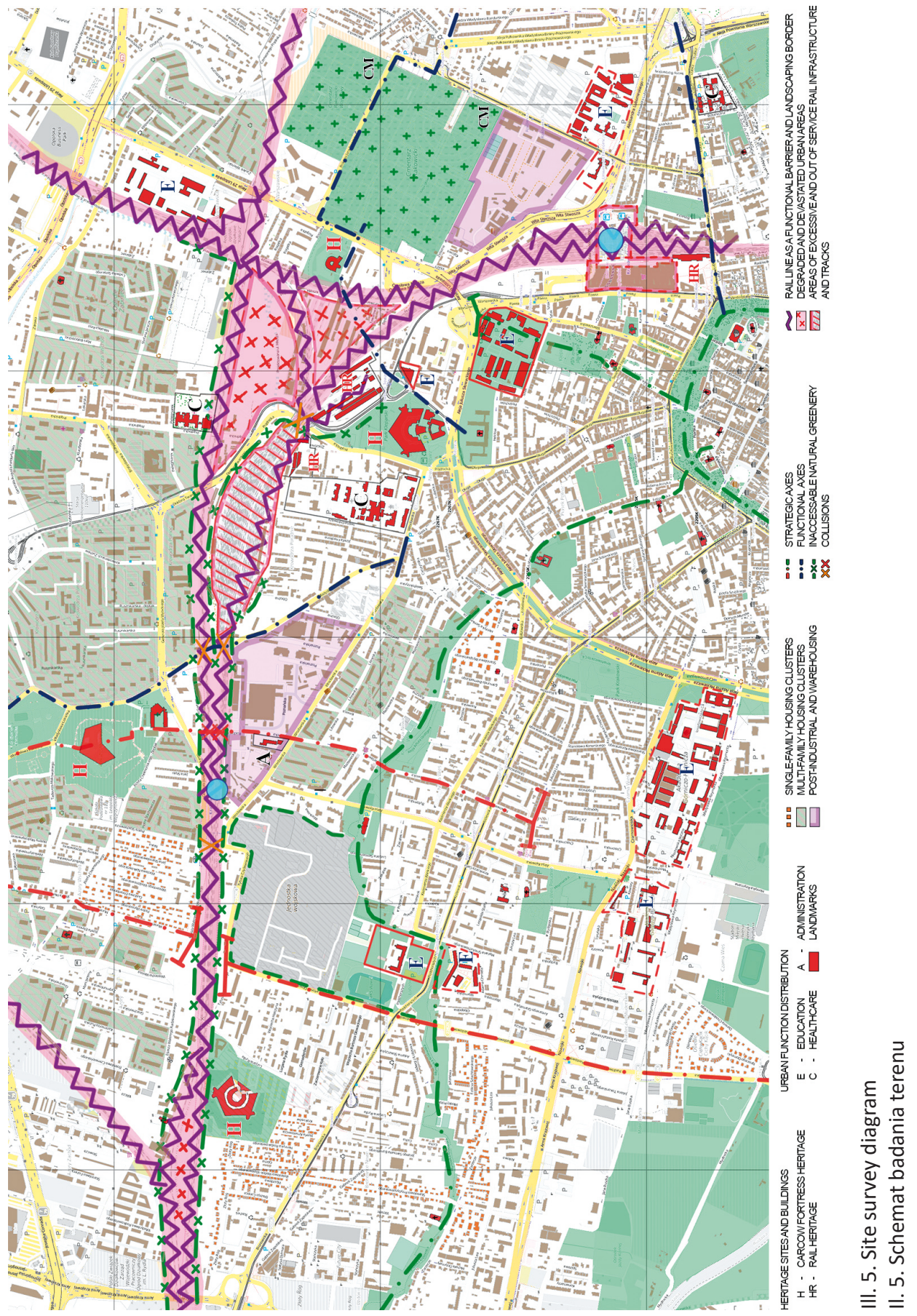




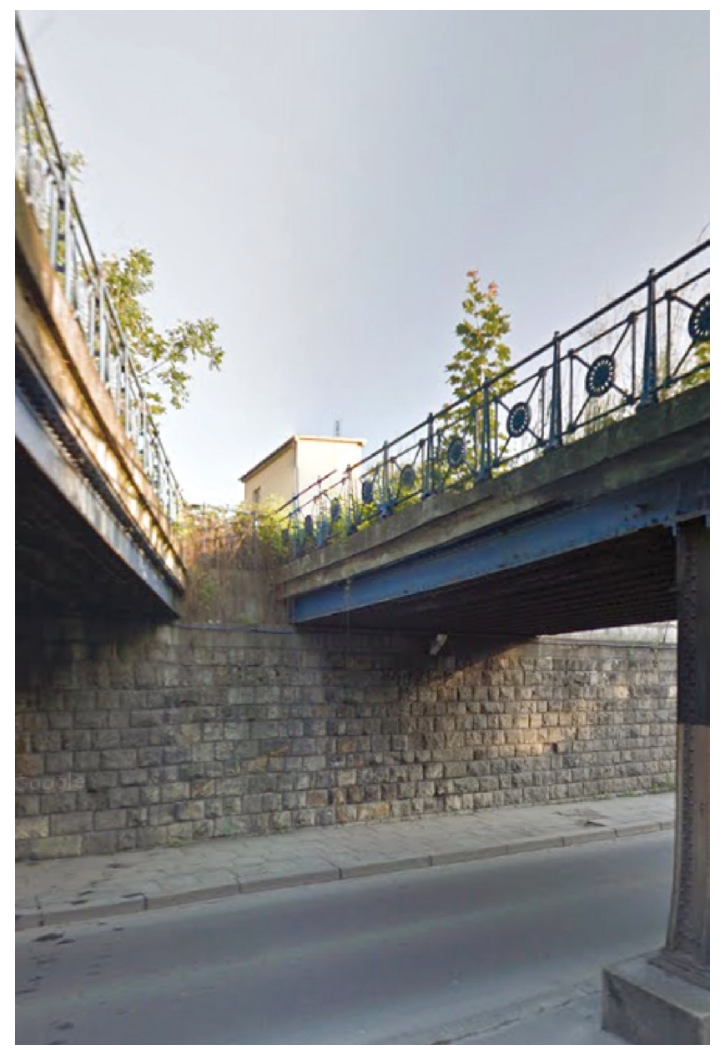

III. 6. Green Bridge concept inspiration

II. 6. Zielony Most - inspiracja koncepcji

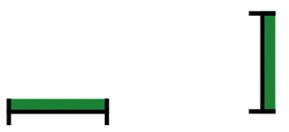

HORIZONTALMODULE VERTICALM.

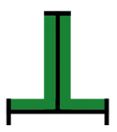

MIXED

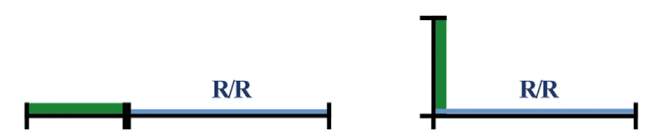

GREEN CORRIDOR AND FUNCTIONAL C. BASICALIGNMENTS
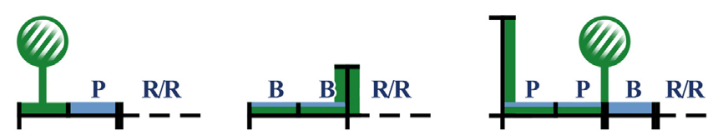

COMPLEX VARIATIONS (tree lines, green walls, areal coridor, etc.)

$R / R$ - railway or road system, $P$ - pedestrians, B - bicycle greenway

III. 7. Green Corridor modular concept

II. 7. Zielony Korytarz - koncepcja modułowa 


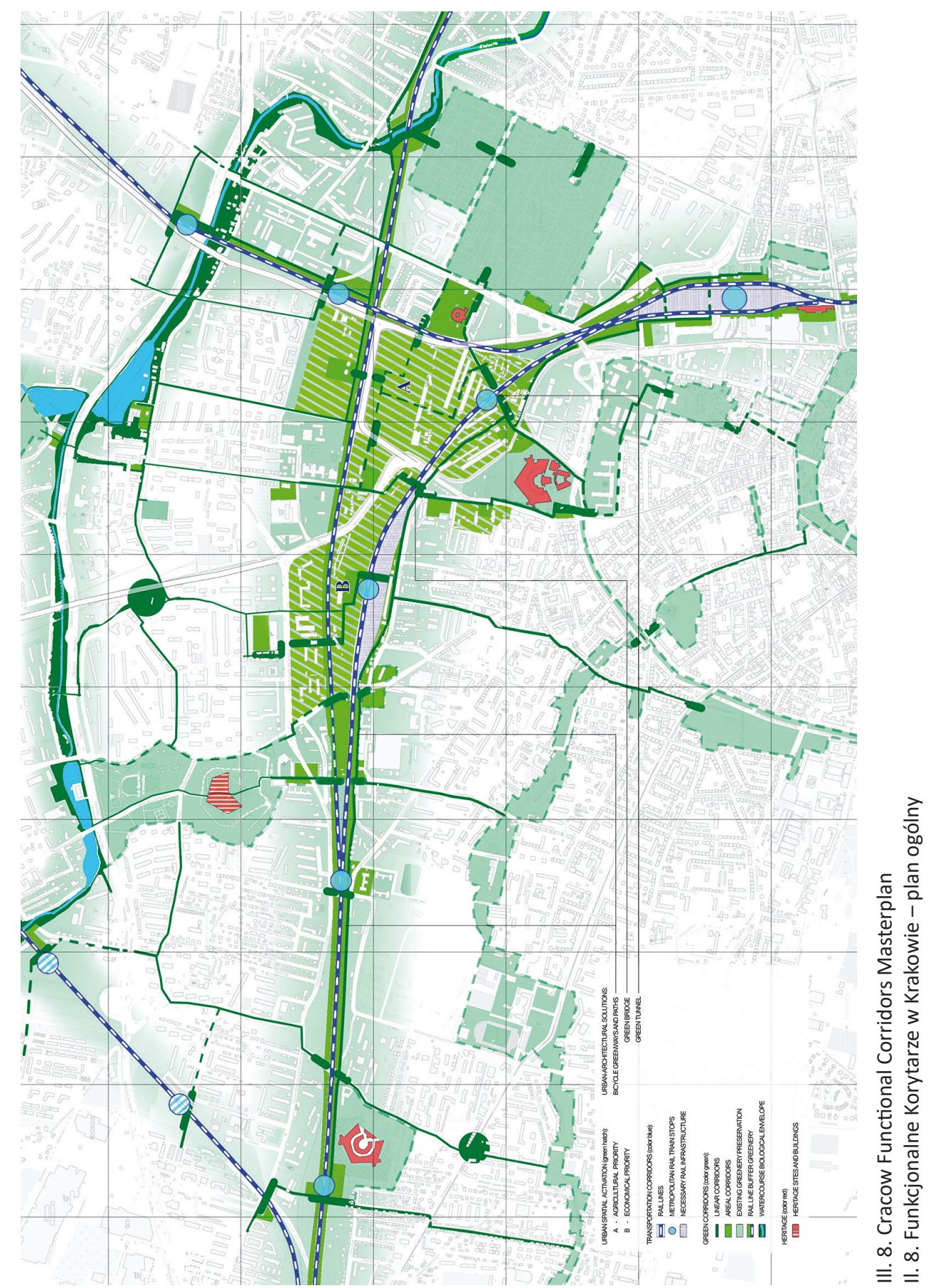




\section{EDNOTES}

1 Analysis period stretches out from the early 18th century until the year 1914.

2 According to the city's plan from the year 1831 the area was beyond the continuous dense urban structure. It was equipped with recently built manor house and several utility buildings for the agricultural purpose.

3 Technological innovations were in favour of development of the rail. For the passengers' comfort electrical lighting was available in long-distance steam trains from 1893. Such interstate routes were also equipped with a telegraph as a strategic domestic communication system.

4 Polish: Kronika kilku dni z Widokami z okna pracowni na Kopiec Kościuszki.

5 A city park referred to as Planty.

6 „Miasta-Ogrody”, Architekt, XIII. 8 (Aug. 1912), p. 82-83.

7 Scientific research and conceptual proposal were accomplished during the Urban Design Workshop I: Barriers-Borders-Edges (17 Oct.-29 Nov. 2014) held by the Urban Composition Department (A-31) of the Institute of Urban Design (A-3), College of Architecture, Cracow University of Technology. An obligatory course for the PhD Studies Programme of the academic year 2014/2015. Course supervisors: Associate Prof. Jacek Gyurkovich, Assistant Prof. Mateusz Gyurkovich.

\section{REFERENCES}

Bertolini L., Spit T., Cities on Rails - The redevelopment of railway station areas, E\&FN Spon, London 1998.

Bogdanowski J., Warownie i zieleń twierdzy Kraków, Wydawnictwo Literackie, Kraków 1979. Bogdanowski J., Fortyfikacje austriackie na terenie Galicji w latach 1850-1914, Krakowski Oddział Towarzystwa Polsko-Austriackiego, Kraków 1993.

Demel J., Poczq̨tki kolei żelaznej w Krakowie, Towarzystwo Miłośników Historii i Zabytków Krakowa, Kraków 1954.

Frąckowiak M. (red.), Kolejnictwo polskie, Quixi Media, 2013.

Gehl J., Miasta dla ludzi, RAM, Kraków 2014.

Klimas M., Lesiak-Przybył B., Sokół A., Wielki Kraków: Rozszerzenie granic miasta w latach 1910-1915: Wybrane materiały ze zbiorów Archiwum Państwowego w Krakowie, Archiwum Państwowe w Krakowie, Kraków 2010.

Lynch K., The Image of the City, MIT Press, Cambridge 1960.

Mazan L., 150 lat dróg żelaznych w Galicji: 1847-1997, Kolejowa Oficyna Wydawnicza, Warszawa 1997.

Mollison B., Introdução à permacultura, Novotempo, 2003.

Wejchert K., Elementy kompozycji urbanistycznej, Arkady, Warszawa 1974. 
Metzger J.P., Como restaurar a conectividade de paisagens fragmentadas?, [in:] Restauração ecológica de ecossistemas naturais, Botucatu: FEPAF, 2003, p. 49-76.

Komorowski W., Pierwszy krakowski dworzec kolejowy, „Rocznik Krakowski”, 60, 1994, p. 75-94.

Komorowski W., Stacja kolejowa Kraków Główny Osobowy, „Rocznik Krakowski”, 63, 1997, p. 89-118.

Zaborska-Jagiełło A., Dworzec Towarowy w Krakowie jako obszar strategicznej interwencji, "Czasopismo Techniczne”, 1-A/2011, p. 185-194. 